\title{
ZADŁUŻENIE GOSPODARSTW DOMOWYCH JAKO POCHODNA ICH DOCHODU
}

\begin{abstract}
Cel pracy stanowiła próba wyjaśnienia powiązań, jakie istnieją pomiędzy poziomem zadłużenia gospodarstw domowych a poziomem dochodów pozostających do ich dyspozycji. Poszukiwano odpowiedzi na pytania, czy wzrost zadłużenia gospodarstw domowych wynika z niewystarczającego, w ocenie tych podmiotów, poziomu dochodów, czy też przeciwnie - zadłużenie gospodarstw domowych rośnie, gdyż w świetle ich sytuacji materialnej moga sobie one na to pozwolić? W pracy postawiono hipotezę badawczą, że ,wyższy poziom dochodów rozporządzalnych gospodarstw domowych sprzyja powstawaniu ich większego zadłużenia”. W celu zweryfikowania tej hipotezy przeprowadzono, na podstawie danych publikowanych przez OECD oraz BFG, KNF, NBP i ZBP, analizę zadłużenia i dochodów rozporządzalnych gospodarstw domowych w wybranych krajach na świecie oraz w Polsce. Efekty rozważań prowadzą do wniosku, że w krajach lepiej rozwiniętych gospodarczo poziom zadłużenia gospodarstw domowych w relacji do ich dochodów do dyspozycji jest wyższy niż w krajach znajdujących się na niższym poziomie rozwoju. Z poziomem rozwoju danego kraju powiązana jest również struktura zadłużenia posiadanego przez gospodarstwa domowe - w krajach o wyższym poziomie rozwoju istnieje przewaga zadłużenia mieszkaniowego nad zadłużeniem konsumpcyjnym, podczas gdy w krajach gorzej rozwiniętych zależność ta jest odwrotna. W Polsce poziom zadłużenia gospodarstw domowych wyrażony w procentach dochodu do dyspozycji jest na jednym z najniższych poziomów w Europie, niemniej jednak tempo wzrostu zadłużenia mieszkaniowego przewyższa na ogół tempo wzrostu zadłużenia konsumpcyjnego, a od 2008 r. poziom zadłużenia mieszkaniowego jest wyższy niż poziom zadłużenia konsumpcyjnego.
\end{abstract}

Słowa kluczowe: gospodarstwo domowe, zadłużenie, dochód rozporządzalny, popyt mieszkaniowy, popyt konsumpcyjny

\section{WPROWADZENIE}

Poziom zadłużenia gospodarstw domowych ${ }^{3}$ jest niewątpliwie związany z poziomem dochodów, jakie pozostają w ich dyspozycji ${ }^{4}$. Można tutaj zauważyć dwojakiego rodzaju zależności: po pierwsze gospodarstwa domowe, dla których posiadany dochód okazuje się

\footnotetext{
${ }^{1}$ Agata Gemzik-Salwach, dr, Wyższa Szkoła Informatyki i Zarządzania z siedzibą w Rzeszowie, ul. H. Sucharskiego 2, 35-225 Rzeszów, tel.: 1786612 43, e-mail: agemzik@wsiz.rzeszow.pl (autor korespondencyjny).

${ }^{2}$ Paweł Perz, dr inż., Zakład Finansów, Bankowości i Rachunkowości, Politechnika Rzeszowska, ul. Powstańców Warszawy 8, 335-959 Rzeszów, tel.: 17 8651379, e-mail: pperz@ prz.edu.pl.

${ }^{3}$ Kategoria zadłużenia gospodarstw domowych jest rozumiana w niniejszym opracowaniu zgodnie $\mathrm{z}$ metodologią stosowaną w systemie rachunków narodowych i oznacza wszystkie zobowiązania gospodarstw domowych, które wymagają płatności lub płatności odsetek.

${ }^{4}$ Kategoria dochodów rozporządzalnych do dyspozycji jest rozumiana w niniejszym opracowaniu zgodnie $\mathrm{z}$ metodologia stosowana $\mathrm{w}$ systemie rachunków narodowych i oznacza dochody pierwotne brutto, skorygowane o: podatki od dochodów i majątku, składki na obowiązkowe ubezpieczenia społeczne, świadczenia $\mathrm{z}$ ubezpieczeń społecznych i z pomocy społecznej oraz różne transfery bieżące.
} 
niewystarczający, sięgają po pożyczki i kredyty konsumpcyjne, aby zapewnić sobie zaspokojenie określonych potrzeb, co oznacza wzrost ich zadłużenia ${ }^{5}$. Po drugie uzyskanie kredytu wymaga osiągnięcia pewnego poziomu zdolności kredytowej, zależnej od posiadanego dochodu. Oznacza to, że osoby, dla których wysokości odsetek i rat kredytowych są zbyt wysokie w stosunku do posiadanego dochodu, aby umożliwić ich „,normalne” funkcjonowanie, nie mogą dostać kredytu ${ }^{6}$. Relacje te dotyczą szczególnie kredytów długoterminowych i na większe kwoty, takich jak kredyty hipoteczne. W ostatnich latach tendencja ta wzmacnia się ze względu na wprowadzane nowe normy ostrożnościowe obowiązujące banki. Jak widać, zależność pomiędzy dochodami a zadłużeniem gospodarstw domowych jest $\mathrm{w}$ tym wypadku odwrotna do poprzedniej. Można więc mówić o dwóch przeciwnie działających na siebie związkach. Wyższy poziom dochodu pozostającego w dyspozycji gospodarstw domowych powinien, w myśl przedstawionych zależności, ograniczać ich zadłużenie krótkoterminowe, ukierunkowane na realizacje bieżących potrzeb oraz sprzyjać wzrostowi zadłużenia długoterminowego.

Celem artykułu jest próba wyjaśnienia powiązań, jakie istnieją pomiędzy poziomem zadłużenia gospodarstw domowych a poziomem dochodów rozporządzalnych pozostających do ich dyspozycji. Poszukiwana jest odpowiedź na pytania, czy wzrost zadłużenia gospodarstw domowych wynika z niewystarczającego, w ocenie tych podmiotów, poziomu dochodów, czy też przeciwnie - zadłużenie gospodarstw domowych rośnie, gdyż w świetle ich sytuacji materialnej mogą sobie one na to pozwolić? W pracy postawiono hipotezę badawczą, że ,wyższy poziom dochodów rozporządzalnych gospodarstw domowych sprzyja powstawaniu ich większego zadłużenia”.

Tak sformułowany cel pracy oraz hipoteza badawcza uwarunkowały strukturę opracowania. W pierwszej części artykułu dokonano przeglądu prowadzonych wcześniej badań empirycznych, dotyczących poruszanego obszaru. Następnie przeprowadzono analizy kształtowania się poziomu zadłużenia gospodarstw domowych i poziomu ich dochodu rozporządzalnego oraz wzajemnych relacji zachodzących pomiędzy tymi dwiema zmiennymi. Badaniu poddano zarówno sytuację gospodarstw domowych w Polsce, jak i na świecie. Analiza obejmowała lata 1995-2014. W badaniach wykorzystano dane empiryczne publikowane przez Organizację Współpracy Gospodarczej i Rozwoju (OECD, Organization for Economic Cooperation and Development) oraz Bankowy Fundusz Gwarancyjny (BFG), Komisję Nadzoru Finansowego (KNF), Narodowy Bank Polski (NBP) $i$ Związek Banków Polskich (ZBP). Skupiono się na długu gospodarstw domowych zaciągniętym w sektorze bankowym, natomiast pominięto, ze względu na brak oficjalnych statystyk, problem zadłużenia w sektorze pozabankowym. Praca została zakończona podsumowaniem, na które złożyły się sformułowane wnioski oraz wskazane przyszłe kierunki badań.

\section{PRZEGLĄD WCZEŚNIEJ PROWADZONYCH BADAŃ}

Raporty dotyczące poziomu zadłużenia, w tym zadłużenia prywatnego, poszczególnych społeczeństw były regularnie publikowane przez McKinsey Global Institute ${ }^{7}$. Wska-

\footnotetext{
${ }^{5}$ O.J. Haas, Over-indebtedness in Germany, Employment section, „Social Finance Program” 2006/44, .

${ }^{6}$ Zob. M. Marcinkowska, Standardy kapitatowe banków. Bazylejska Nowa Umowa Kapitałowa w polskich regulacjach nadzorczych, Regan Press, Gdańsk 2009, s. 71-80.

${ }^{7}$ C. Roxburgh, S. Lund, T. Daruvala, J. Manyika, R. Dobbs, R. Forn, K. Croxson, Debt and deleveraging: Uneven progress on the path to growth, McKinsey Global Institute, January 2012; C. Roxburgh, S. Lund,
} 
zywały one na gwałtowny wzrost zadłużenia gospodarstw domowych i jego niewielkie ograniczanie w krajach szczególnie mocno dotkniętych kryzysem finansowym (Stany Zjednoczone, Wielka Brytania, Hiszpania i Irlandia). Kredyty hipoteczne zostały tu wskazane jako główne źródło zadłużenia gospodarstw domowych w krajach bardziej rozwiniętych. Z kolei badania przeprowadzone przez Reinharta, Reinharta i Rogoffa ${ }^{8}$ wskazały na zależność pomiędzy długiem a poziomem rozwoju gospodarczego. Autorzy ci doszli do wniosku, że wysokie zadłużenie krajów ma związek z ich wolniejszym tempem wzrostu PKB. Do tych samych wniosków doszli Cecchetti, Mohanty i Zampolli, zwracając dodatkowo uwagę na większe ryzyko kryzysów gospodarczych w tych państwach. Na ciągły wzrost zadłużenia gospodarstw domowych wskazuje też praca Buttiglione, Lane, Reichlina i Reinharta ${ }^{10}$. Również tutaj wzrost zadłużenia gospodarstw domowych potraktowany został jako symptom przyszłych zagrożeń.

Zadłużenie gospodarstw domowych w strefie euro było przedmiotem badań GomezSalvador, Lojschova i Westermanna ${ }^{11}$. Autorzy ci wykazali, że skłonność do nadmiernego zadłużania się stanowi duży problem. W ich badaniach szczególną skłonność do zwiększania długu wykazywały gospodarstwa domowe o niskim dochodzie rozporządzalnym.

Odrębnym zagadnieniem jest rola, jaką odgrywają zmiany poziomu zadłużenia gospodarstw domowych w funkcjonowaniu gospodarki. W literaturze przedmiotu nie została ona jednoznacznie określona. Zagadnieniem tym zajęły się Rytelewska i Huszczonek ${ }^{12}$, które przeprowadziły analizę zmian w popycie na kredyt gospodarstw domowych w latach 1996-2002. Doszły one do wniosku, że poziom zadłużenia gospodarstw domowych w Polsce był w tym okresie znacznie niższy niż w rozwiniętych gospodarkach rynkowych oraz że gospodarstwa domowe zadłużają się głównie w celu sfinansowania bieżących potrzeb oraz remontu mieszkania lub domu. Problemem nadmiernego zadłużania się gospodarstw domowych zajął się zaś Gębski ${ }^{13}$, podkreślając w swoim opracowaniu społeczny charakter i skutki nadmiernego obciążenia długiem.

\section{ZALEŻNOŚCI POMIĘDZY ZADLUŻENIEM A DOCHODAMI ROZPORZĄDZALNYMI W GOSPODARSTWACH DOMOWYCH}

W tabeli 1 przestawiono zadłużenie gospodarstw domowych jako procent dochodów rozporządzalnych w wybranych krajach w latach 1995-2014. Z analizy przedstawionych w niej danych wynika wyraźnie, że poziom zadłużenia w Polsce jest znacznie niższy niż

T. Wimmer, E. Amar, C. Atkins, J. Kwek, R. Dobbs, J. Manyika, Debt and deleveraging: The global credit bubble and its economic consequences, McKinsey Global Institute, January 2010; R. Dobbs, S. Lund, J. Woetzel, M. Mutafchieva, Debt and (not much) deleveraging, McKinsey Global Institute, February 2015.

${ }^{8}$ C.M. Reinhart, V.R. Reinhart, K.. Rogoff, Public debt overhangs: Advanced economy episodes since 1800, „Journal of Economic Perspectives” 26/3 (2012).

${ }^{9}$ S.G. Cecchetti, M.S. Mohanty, F. Zampolli, The real effects of debt, „Bank for International Settlements (BIS) Working Paper" 2011/352.

${ }^{10}$ L. Buttiglione, P.R. Lane, L. Reichlin, V. Reinhart, Deleveraging? What Deleveraging?, „Geneva Reports on the World Economy" 2014/16.

${ }^{11}$ R. Gomez-Salvador, A. Lojschova, T. Westermann, Household sector borrowing in the Euro area - a microdata perspective, „European Central Bank Occasional Paper Series” 2011/125.

${ }^{12}$ G. Rytelewska, E. Huszczonek, Zmiany w popycie na kredyt gospodarstw domowych, „Materiały i Studia, NBP” 2004/172.

13 Ł. Gębski, Nadmierne zadtużenie gospodarstw domowych - problem finansowo-prawny czy społeczny?, Gospodarka Narodowa, nr 4, 2013, s. 83-108. 
w krajach bardziej rozwiniętych - jest to zgodnie z badaniami przeprowadzonymi przez Rytelewską i Huszczonek ${ }^{14}$. Wyniki te mogłyby stanowić potwierdzenie postawionej hipotezy. W rozwiniętych gospodarkach rynkowych kredyt stanowi podstawowe narzędzie finansowania potrzeb gospodarstw domowych. Poziom zadłużenia gospodarstw domowych w relacji do nominalnych dochodów do dyspozycji w poszczególnych krajach jest zróżnicowany. W większości państw analizowane wskaźniki wykazywały tendencję rosnącą w latach 1995-2011, po roku 2011 daje się zauważyć nieznaczny spadek wielkości tego wskaźnika. Można przypuszczać, że jest to efekt zmian i reform wprowadzanych po światowym kryzysie finansowym z $2008 \mathrm{r}$.

Tabela 1. Zadłużenie gospodarstw domowych jako procent nominalnych dochodów do dyspozycji w wybranych krajach w latach 1995-2014

\begin{tabular}{|c|c|c|c|c|c|c|c|c|}
\hline & Francja & Japonia & Kanada & Niemcy & Polska & $\begin{array}{l}\text { Stany Zjed- } \\
\text { noczone }\end{array}$ & $\begin{array}{l}\text { Wielka } \\
\text { Brytania }\end{array}$ & Włochy \\
\hline 1995 & 66,41 & 137,36 & 98,57 & 97,21 & - & 94,47 & - & 38,43 \\
\hline 1996 & 69,59 & 139,27 & 102,46 & 101,85 & - & 96,27 & - & 39,60 \\
\hline 1997 & 72,78 & 137,69 & 105,86 & 105,37 & - & 97,36 & 111,18 & 42,07 \\
\hline 1998 & 72,43 & 137,85 & 108,29 & 109,88 & - & 98,25 & 114,40 & 45,96 \\
\hline 1999 & 74,95 & 139,32 & 110,90 & 114,77 & - & 102,17 & 117,30 & 50,74 \\
\hline 2000 & 74,76 & 140,74 & 110,12 & 116,52 & - & 103,50 & 118,94 & 54,47 \\
\hline 2001 & 77,03 & 140,67 & 110,76 & 112,98 & - & 107,20 & 125,62 & 56,52 \\
\hline 2002 & 77,46 & 139,47 & 114,37 & 113,58 & - & 112,44 & 138,83 & 59,35 \\
\hline 2003 & 81,13 & 138,07 & 119,35 & 111,97 & 19,70 & 120,28 & 151,67 & 62,54 \\
\hline 2004 & 81,93 & 137,38 & 124,78 & 110,39 & 21,57 & 126,93 & 164,93 & 66,22 \\
\hline 2005 & 88,41 & 137,88 & 132,12 & 108,06 & 24,96 & 134,58 & 167,16 & 71,25 \\
\hline 2006 & 93,58 & 137,30 & 135,19 & 105,72 & 31,18 & 139,70 & 178,84 & 76,11 \\
\hline 2007 & 96,65 & 133,65 & 143,39 & 102,65 & 39,19 & 143,09 & 183,27 & 80,18 \\
\hline 2008 & 98,69 & 132,25 & 148,43 & 99,40 & 51,48 & 135,34 & 178,14 & 81,60 \\
\hline 2009 & 104,25 & 132,39 & 157,38 & 100,29 & 52,85 & 133,75 & 167,51 & 86,52 \\
\hline 2010 & 107,53 & 131,90 & 160,17 & 98,25 & 57,16 & 127,23 & 158,73 & 90,37 \\
\hline 2011 & 107,07 & 128,26 & 161,54 & 96,48 & 60,68 & 119,05 & 159,13 & 89,90 \\
\hline 2012 & 103,42 & 127,07 & 163,06 & 95,48 & 58,59 & 113,64 & 153,68 & 92,01 \\
\hline 2013 & 103,84 & 129,18 & 163,77 & 94,45 & 59,45 & 115,09 & 152,04 & 90,62 \\
\hline 2014 & 104,74 & - & 166,10 & 93,58 & - & 113,43 & 155.65 & 90,06 \\
\hline
\end{tabular}

Źródło: opracowanie własne na podstawie: OECD, Household debt (indicator), 2015, doi: 10.1787/f03b6469-en (dostęp: 02.10.2015).

W 2014 r. relacja poziomu zadłużenia gospodarstw domowych do ich dochodów nominalnych wynosiła 90-166\%. Najwyższymi wartościami tego wskaźnika charakteryzowały się gospodarki Kanady i Wielkiej Brytanii. Więcej danych można uzyskać dla roku

\footnotetext{
${ }^{14}$ G. Rytelewska, E. Huszczonek, Zmiany w popycie..., op. cit., s. 9-10.
} 
2013. Podobnie jak poprzednio, również tutaj widać, że w krajach lepiej rozwiniętych mierniki zadłużenia gospodarstw domowych ukształtowały się na wyższych poziomach. W Polsce poziom zadłużenia gospodarstw domowych w relacji do ich dochodów rozporządzalnych w 2013 r. wyniósł 59\% i był niższy niż we wszystkich pozostałych analizowanych krajach. Zależności te zaprezentowano na rysunkach 1 i 2.

Rys. 1. Zadłużenie gospodarstw domowych jako procent nominalnych dochodów do dyspozycji w wybranych krajach w 2014 r.

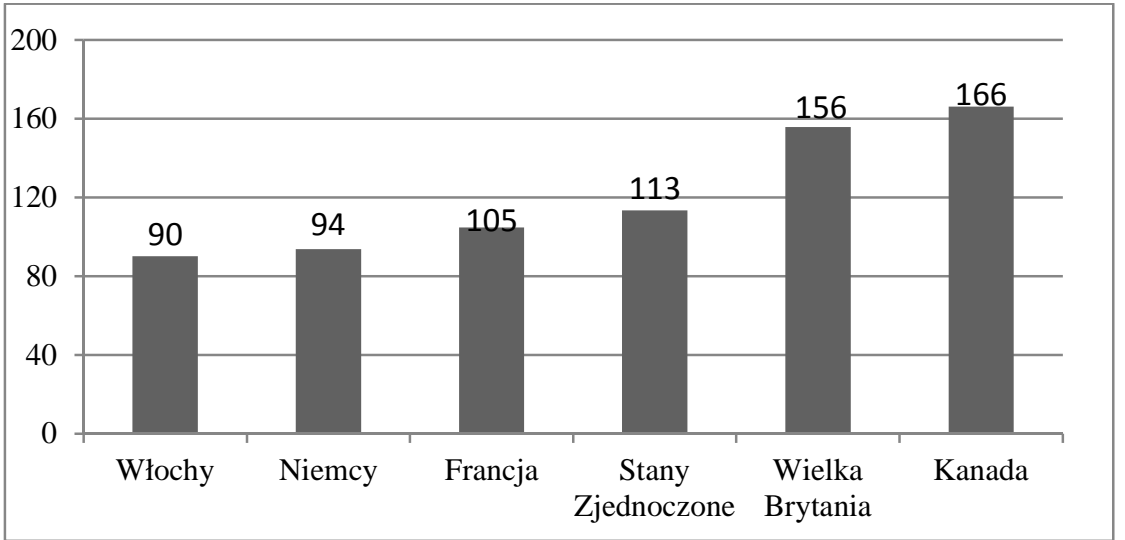

Źródło: opracowanie własne na podstawie: OECD, Household debt (indicator), 2015, doi: 10.1787/f03b6469-en (dostęp: 02.10.2015).

Rys. 2. Zadłużenie gospodarstw domowych jako procent nominalnych dochodów do dyspozycji w wybranych krajach w 2013 r.

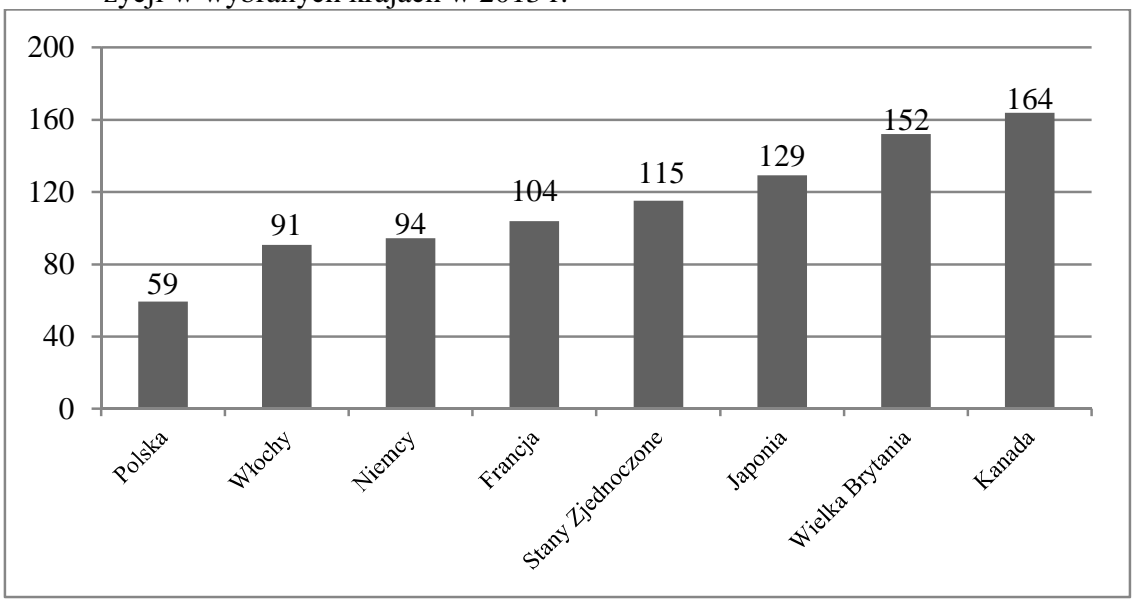

Źródło: opracowanie własne na podstawie: OECD, Household debt (indicator), 2015, doi: 10.1787/f03b6469-en (dostęp: 02.10.2015).

Do podobnych wniosków prowadzi analiza rankingu krajów europejskich o najwyższym poziomie zadłużenia gospodarstw domowych w relacji do dochodów rozporządzalnych krajów (rys. 3 i 4). Po sporządzeniu takiego rankingu okazuje się, że największe 
zadłużenie gospodarstw domowych $\mathrm{w}$ stosunku do ich dochodów istnieje w większości w najzamożniejszych krajów Europy, co nie idzie w parze z przytoczonymi wcześniej wynikami badań Reinharta, Reinharta i Rogoffa ${ }^{15}$ oraz Cecchetti, Mohanty i Zampolli16. Przyczyna rozbieżności w wynikach badań może tkwić w rodzaju długu, który został wzięty pod uwagę. W niniejszym artykule analizie poddano zadłużenie gospodarstw domowych, podczas gdy wymienieni autorzy rozważają zadłużenie na poziomie całego kraju.

Rekordzistą, jeśli chodzi o zadłużenie, jest Dania, która od lat utrzymuje największy stopień zadłużenia - w 2014 r. było to 313\%. Na kolejnych miejscach znalazły się Holandia, Norwegia, Irlandia i Szwecja. Z kolei pięć krajów o najniższym zadłużeniu w 2014 r. to Węgry, Słowenia, Słowacja, Czechy i Estonia. W bazie zabrakło danych dla Polski w 2014 r., jednak w 2013 r. uplasowała się ona na czwartym miejscu od końca, pomiędzy Słowenią a Czechami.

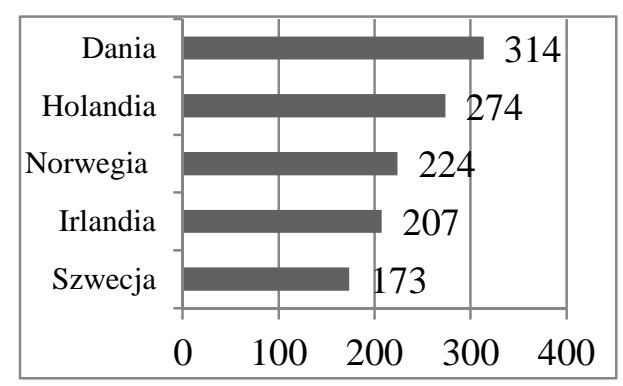

Rys. 3. Kraje europejskie o najwyższym poziomie zadłużenia gospodarstw domowych w relacji do dochodów rozporządzalnych w $2014 \mathrm{r}$.

Źródło: opracowanie własne na podstawie: OECD, Household debt (indicator), 2015, doi: 10.1787/f03b6469-en (dostęp: 02.10.2015).

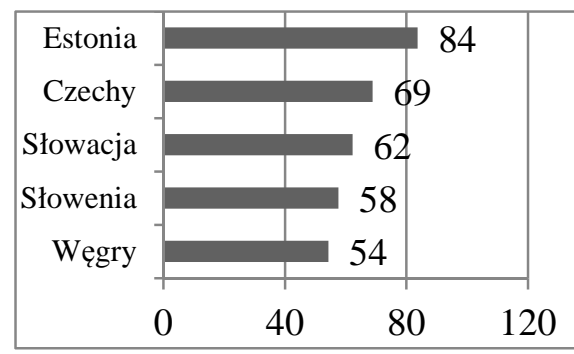

Rys. 4. Kraje europejskie o najniższym poziomie zadłużenia gospodarstw domowych w relacji do dochodów rozporządzalnych w 2014 r.

Źródło: opracowanie własne na podstawie: OECD, Household debt (indicator), 2015, doi: 10.1787/f03b6469-en (dostęp: 02.10.2015).

Należy zauważyć, że wzrost wartości zadłużenia gospodarstw domowych w relacji do ich rozporządzalnych dochodów nie powoduje wprost proporcjonalnego wzrostu liczby przypadków określanych jako problem nadmiernego zadłużenia. Wyniki te są zgodne z rezultatami badań Gębskiego ${ }^{17}$, który zwraca przy tym uwagę na to, że istotnymi elementami w tym wypadku są stabilność gospodarki oraz nawyki konsumentów. Warto również odnotować, że w wymienionych krajach o najwyższym zadłużeniu istnieje tzw. „kultura kredytowa” polegająca na tym, że portfele kredytowe banków są dobrej jakości, a klienci obsługują zaciągnięte zobowiązania, podczas gdy w krajach o najniższym zadłużeniu mamy do czynienia z dużym udziałem niezabezpieczonych kredytów konsumpcyjnych w sektorze bankowym.

\footnotetext{
${ }^{15}$ C.M. Reinhart, V.R. Reinhart, K.S. Rogoff, op. cit.

${ }^{16}$ S.G. Cecchetti, M.S. Mohanty, F. Zampolli, op. cit.

${ }^{17}$ Ł. Gębski, op. cit., s. 97-98.
} 
Przyczyn takiej sytuacji należy upatrywać również w celach, na które przeznaczane jest zadłużenie. Nadmierne zadłużenie występuje na ogół wtedy, gdy konsumenci wydają pożyczone pieniądze na bezpośrednią konsumpcję, a nie na zakup dóbr trwałego użytku. W krajach, w których relatywny poziom zadłużenia jest najwyższy, na ogół zachodzi sytuacja, w której konsumenci przeznaczają zadłużenie na pokrycie kosztów zakupów o charakterze trwałym. Jest to zgodnie $\mathrm{z}$ wynikami badań zaprezentowanymi przez McKinsey Global Institute ${ }^{18}$ oraz Mian i Sufi ${ }^{19}$, w których wykazano, że kredyty hipoteczne są główną formą zadłużenia gospodarstw domowych we wszystkich gospodarkach rozwiniętych, oraz udowodniono istnienie silnej korelacji pomiędzy wzrostem cen nieruchomości a poziomem zadłużenia gospodarstw domowych.

W Polsce poziom zadłużenia gospodarstw domowych w relacji do ich dochodów rozporządzalnych jest jednym z najniższych w Europie. Struktura tego zadłużenia stopniowo zmienia się: do 2007 r. była charakterystyczna dla krajów słabiej rozwiniętych - zadłużenie konsumpcyjne przewyższało zadłużenie mieszkaniowe, a od 2008 r. proporcje te się odwróciły. Dane te zaprezentowano w tabeli 2.

Tabela 2. Struktura kredytów dla sektora niefinansowego w Polsce (\%)

\begin{tabular}{|c|c|c|c|c|c|c|}
\hline & $\begin{array}{c}\text { Kredyty } \\
\text { konsump- } \\
\text { cyjne }\end{array}$ & $\begin{array}{c}\text { Kredyty } \\
\text { mieszka- } \\
\text { niowe }\end{array}$ & $\begin{array}{c}\text { Inne dla } \\
\text { gospodarstw } \\
\text { domowych }\end{array}$ & $\begin{array}{c}\text { Kredyty } \\
\text { dla przed- } \\
\text { siębiorstw }\end{array}$ & $\begin{array}{c}\text { Kredyty dla } \\
\text { mikro-, małych } \\
\text { i średnich przed- } \\
\text { siębiorstw }\end{array}$ & $\begin{array}{c}\text { Kredyty } \\
\text { dla dużych } \\
\text { przedsię- } \\
\text { biorstw }\end{array}$ \\
\hline $\mathbf{1 - 2 0 0 3}$ & 19,6 & 9,9 & 12,7 & 57,8 & - & - \\
\hline $\mathbf{1 - 2 0 0 4}$ & 18,9 & 13,6 & 12,2 & 55,3 & - & - \\
\hline $\mathbf{1 - 2 0 0 5}$ & 20,4 & 15,9 & 12,4 & 51,4 & - & - \\
\hline $\mathbf{1 - 2 0 0 6}$ & 21,6 & 19,8 & 11,8 & 46,8 & - & - \\
\hline $\mathbf{1 - 2 0 0 7}$ & 21,2 & 24,9 & 11,9 & 42,1 & - & - \\
\hline $\mathbf{1 - 2 0 0 8}$ & 21,1 & 28,1 & 11,0 & - & 22,9 & 16,8 \\
\hline $\mathbf{1 - 2 0 0 9}$ & 20,1 & 33,7 & 9,5 & - & 19,7 & 16,9 \\
\hline $\mathbf{1 - 2 0 1 0}$ & 21,6 & 34,7 & 10,2 & - & 19,1 & 14,4 \\
\hline $\mathbf{1 - 2 0 1 1}$ & 20,3 & 38,7 & 10,5 & - & 17,7 & 12,9 \\
\hline $\mathbf{1 - 2 0 1 2}$ & 17,4 & 40,5 & 10,4 & - & 18,8 & 12,8 \\
\hline $\mathbf{1 - 2 0 1 3}$ & 16,4 & 41,0 & 10,9 & - & 19,1 & 12,5 \\
\hline $\mathbf{1 - 2 0 1 4}$ & 16,3 & 41,6 & 11,2 & - & 18,2 & 12,7 \\
\hline $\mathbf{1 - 2 0 1 5}$ & 16,0 & 42,6 & 11,1 & - & 17,6 & 12,8 \\
\hline
\end{tabular}

Źródło: opracowanie własne na podstawie danych NBP; NBP, Raport o stabilności systemu finansowego. Lipiec 2015 r., Warszawa 2015; ZBP, Raport Amron-SARFiN. Ogólnopolski raport o kredytach mieszkaniowych i cenach transakcyjnych nieruchomości, III kwartał 2009.

Tempo wzrostu zadłużenia mieszkaniowego gospodarstw domowych w Polsce przewyższało na ogół tempo wzrostu ich zadłużenia konsumpcyjnego. Od 2008 r. roczne tem-

\footnotetext{
${ }^{18}$ R. Dobbs, S. Lund, J. Woetzel, M. Mutafchieva, op. cit., s. 6-8.

${ }^{19}$ A. Mian, A. Sufi, House of Debt: How they (and you) caused the Great Recession, and how we can prevent it from happening again, University of Chicago Press, Chicago 2014.
} 
po wzrostu kredytów mieszkaniowych stopniowo się zmniejszało. Było to efektem między innymi stopniowego spadku stanu kredytów walutowych i wzrostu kredytów złotówkowych. W ograniczonym stopniu znaczenie miało tu wprowadzanie rządowego programu „Mieszkanie dla Młodych”20. Z kolei tempo wzrostu kredytów konsumpcyjnych w analizowanym okresie rosło do 2008 r., by następnie spadać aż do 2013 r. Od stycznia 2011 roku do sierpnia 2013 tempo wzrostu zadłużenia konsumpcyjnego było ujemne (rys. 5).

Rys. 5. Roczne tempo wzrostu zadłużenia konsumpcyjnego oraz mieszkaniowego gospodarstw domowych w sektorze bankowym w Polsce

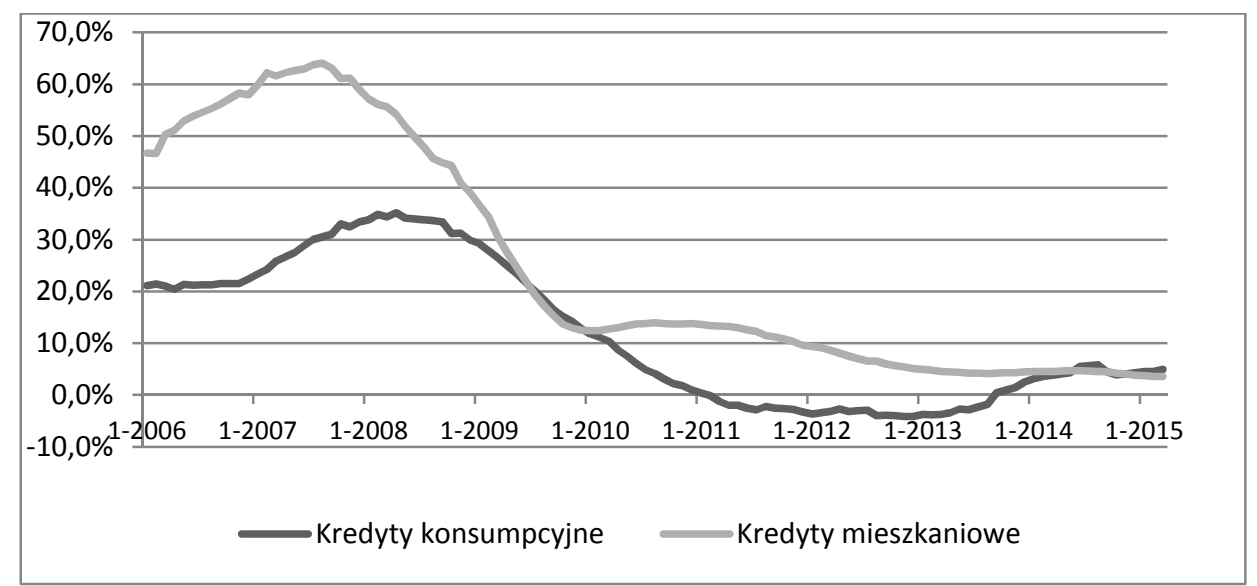

Źródło: opracowanie własne na podstawie danych BFG, NBP i ZBP; BFG, Sytuacja $w$ sektorze bankowym. Informacja miesięczna, wrzesień, 2015; NBP, Raport o stabilności systemu finansowego. Lipiec 2015 r., Warszawa 2015; ZBP, Raport Amron-SARFiN, Ogólnopolski raport o kredytach mieszkaniowych i cenach transakcyjnych nieruchomości, III kwartał 2009.

Duży spadek tempa wzrostu zadłużenia mieszkaniowego i konsumpcyjnego w Polsce był spowodowany zaostrzeniem polityki kredytowej banków po kryzysie finansowym. Zmiany polityki kredytowej stosowanej przez banki były w dużej mierze efektem wprowadzanych zmian regulacyjnych.

\section{WNIOSKI I KIERUNKI PRZYSZŁYCH BADAŃ}

Celem pracy była próba wyjaśnienia powiązań, jakie istnieją pomiędzy poziomem zadłużenia gospodarstw domowych a poziomem dochodów pozostających do ich dyspozycji. Na podstawie przeprowadzonych w artykule analiz można stwierdzić, że kraje lepiej rozwinięte gospodarczo cechuje wyższy poziom zadłużenia gospodarstw domowych w relacji do ich dochodów rozporządzalnych. Z kolei niski poziom tego wskaźnika jest wspólną cechą państw mało zamożnych. Oznaczałoby to potwierdzenie przyjętej w artykule hipotezy mówiącej o istnieniu dodatniej zależności między poziomem dochodów rozporządzalnych gospodarstw domowych, a ich poziomem zadłużenia.

Przyczyn takiego stanu należy upatrywać w jakości udzielanych przez banki kredytów w poszczególnych krajach, stabilności gospodarek oraz nawykach konsumenckich.

${ }^{20}$ Zob. NBP, Raport o stabilności systemu finansowego. Lipiec 2015 r., Warszawa 2015, s. 33. 
W krajach lepiej rozwiniętych można zauważyć wyższy udział kredytów przeznaczonych na cele mieszkaniowe. Zjawisko to niekoniecznie należy oceniać pozytywnie, gdyż towarzyszy mu zwykle silne powiązanie pomiędzy wzrostem cen na rynkach nieruchomości z liczbą zaciąganych kredytów hipotecznych, co z kolei, jak wiadomo, stało się podłożem światowego kryzysu finansowego.

Poziom zadłużenia gospodarstw domowych w relacji do ich dochodu rozporządzalnego w Polsce jest jednym z najniższych w Europie. W strukturze popytu na kredyt do $2007 \mathrm{r}$. przeważał popyt konsumpcyjny, natomiast od 2008 r. można zaobserwować przewagę popytu mieszkaniowego. Z kolei tempo wzrostu zadłużenia mieszkaniowego gospodarstw domowych przewyższa na ogół tempo wzrostu zadłużenia konsumpcyjnego.

Wnioski płynące ze zrealizowanych badań dotyczące optymalnego poziomu zadłużenia powinny być ostrożnie wyciągane . Po pierwsze, zbyt pochopne byłoby stwierdzenie, że Polska, chcąc dołączyć do grupy krajów zamożnych, powinna dążyć do wzrostu zadłużenia gospodarstw domowych. Owszem wzrost zadłużenia tych podmiotów oznacza większe wydatki na konsumpcję i poprzez napędzanie koniunktury sprzyja wzrostowi gospodarczemu. Niemniej jednak należy pamiętać o tworzących się w ten sposób bańkach spekulacyjnych, które spowodowały problemy w części zamożnych społeczeństw. Po drugie, niezmiernie ważny jest cel, na jaki zostanie przeznaczone zadłużenie. Cele mieszkaniowe są lepsze od celów konsumpcyjnych i tutaj zmiany zachodzące w tym obszarze w Polsce można postrzegać pozytywnie. I wreszcie po trzecie, bardzo istotnym, o ile nie najważniejszym czynnikiem jest zachowanie właściwych proporcji pomiędzy zadłużeniem a poziomem dochodu $\mathrm{w}$ gospodarstwach domowych ${ }^{21}$. Osoby o wyższych dochodach mogą sobie pozwolić na wyższe zadłużenie, natomiast grupa osób najbiedniejszych powinna unikać zbytniego zadłużania się, zwłaszcza w celach konsumpcyjnych, gdyż grozi to wpadnięciem w spiralę długu ${ }^{22}$. W tym świetle warto jeszcze wspomnieć o ogromnej roli edukacji ekonomicznej, która powinna zostać ukierunkowana na zagadnienia związane $\mathrm{z}$ zarządzaniem budżetem domowym ${ }^{23}$.

Przyszłe analizy zostaną ukierunkowane na zbadanie związku pomiędzy zadłużeniem gospodarstw domowych a poziomem tak zwanego dochodu oczekiwanego czy permanentnego. Pogłębienie badań będzie dotyczyć uwzględnienia teorii cyklu życia stworzonej przez Modiglianiego i Brumberga ${ }^{24}$ oraz teorii dochodu permanentnego Friedmana ${ }^{25}$. Obie te teorie uwzględniają dodatkowo rozważanie bogactwa i podejmowanie decyzji z udziałem zdyskontowanego na dany moment oczekiwanego strumienia całożyciowych

${ }^{21}$ M. Iwanicz-Drozdowska, A.K. Nowak, Rola i znaczenie edukacji finansowej, [w:] Edukacja i świadomości finansowa, red. M. Iwanicz-Drozdowska, Wydawnictwo SGH, Warszawa 2011, s. 17.

${ }^{22}$ Zob. T. Jappelli, M. Pagano, M. di Maggio, Households' Indebtedness and Financial Fragility, „CSEF Working Paper" 2008/208; W. Simpson, J. Buckland, Examining Evidence of Financial and Credit Exclusion in Canada from 1999 to 2005, ,Journal of Socio-economics” 38/6 (2009), s. 966-976.

${ }^{23}$ Por. S. Flejterski, Świadomość ekonomiczna i społeczna jako determinanta kondycji ekonomicznej gospodarstw domowych na tle badań (wtórnych i pierwotnych), [w:] Bankructwa gospodarstw domowych. Perspektywa ekonomiczna $i$ społeczna, red.B. Świecka, Difin, Warszawa 2008; B. Gontkovičová, E. Dul'ová Spišáková, The Necessity Of Employee Education, „Modern Management Review” 22/1 (2015), s. 131-141; I. Kuchciak, M. Świeszczak, K. Świeszczak, M. Marcinkowska, Edukacja finansowa i inkluzja bankowa w realizacji koncepcji silver economy, Wydawnictwo Uniwersytetu Łódzkiego, Łódź 2014.

${ }^{24}$ F. Modigliani, R. Brumberg, Utility Analysis and the Consumption Function: An Interpretation of CrossSection Data, [w:] Post-Keynesian Economics, red. K.K. Kurihara, N. J. Rutgers University Press, New Brunswick 1954, s. 388-436.

${ }^{25}$ M. Friedman, A Theory of the Consumption Function, Princeton University Press, Princeton 1957. 
dochodów ${ }^{26}$. Umożliwiają one zatem analizę zachowań gospodarstw domowych w obszarze zadłużania się z uwzględnieniem przeprowadzanych przez nie ocen szans na poprawę sytuacji finansowej. Uwzględnienie w kolejnych badaniach znaczenia tych teorii będzie ważnym rozszerzeniem optyki prowadzonych analiz.

\section{LITERATURA}

[1] BFG, Sytuacja w sektorze bankowym. Informacja miesięczna, wrzesień 2015.

[2] Buttiglione L., Lane P.R., Reichlin L., Reinhart V., Deleveraging? What Deleveraging?, „Geneva Reports on the World Economy” 2014/16.

[3] Cecchetti S.G., Mohanty M.S., Zampolli F., The real effects of debt, „Bank for International Settlements (BIS) Working Paper" 2011/352.

[4] Dobbs R., Lund S., Woetzel J., Mutafchieva M., Debt and (not much) deleveraging, McKinsey Global Institute, February 2015.

[5] Flejterski S., Świadomość ekonomiczna i spoteczna jako determinanta kondycji ekonomicznej gospodarstw domowych na tle badań (wtórnych i pierwotnych), [w:] Bankructwa gospodarstw domowych. Perspektywa ekonomiczna i spoteczna, red. B. Świecka, Difin, Warszawa 2008.

[6] Friedman M., A Theory of the Consumption Function, Princeton University Press, Princeton 1957.

[7] Gębski Ł., Nadmierne zadtużenie gospodarstw domowych - problem finansowo-prawny czy spoteczny?, „Gospodarka Narodowa” 2013/4, s. 83-108.

[8] Gomez-Salvador R., Lojschova A., Westermann T., Household sector borrowing in the Euro area - a micro data perspective, „European Central Bank Occasional Paper Series” 2011/125.

[9] Gontkovičová B., Dul'ová Spišáková E., The Necessity Of Employee Education, „Modern Management Review" 22/1 (2015), s. 131-141.

[10] Haas O.J., Over-indebtedness in Germany, Employment section, „Social Finance Program” 2006/44.

[11] Iwanicz-Drozdowska M, Nowak A.K., Rola i znaczenie edukacji finansowej, [w:] Edukacja $i$ świadomości finansowa, red. M. Iwanicz-Drozdowska, Wydawnictwo SGH, Warszawa 2011, s. 17.

[12] Jappelli T., Pagano M., di Maggio M., Households' Indebtedness and Financial Fragility, „CSEF Working Paper” 2008/208.

[13] Kuchciak I., Świeszczak M., Świeszczak K., Marcinkowska M., Edukacja finansowa i inkluzja bankowa $w$ realizacji koncepcji silver economy, Wydawnictwo Uniwersytetu Łódzkiego, Łódź 2014.

[14] Marcinkowska M., Standardy kapitatowe banków. Bazylejska Nowa Umowa Kapitałowa w polskich regulacjach nadzorczych, Regan Press, Gdańsk 2009.

[15] Mian A., Sufi A., House of Debt: How they (and you) caused the Great Recession, and how we can prevent it from happening again, University of Chicago Press, Chicago 2014.

[16] Modigliani F., Brumberg R., Utility Analysis and the Consumption Function: An Interpretation of Cross-Section Data, [w:] Post-Keynesian Economics, red. K.K. Kurihara, N.J. Rutgers University Press, New Brunswick 1954, 388-436.

[17] NBP, Raport o stabilności systemu finansowego. Lipiec 2015 r., Warszawa 2015.

[18] OECD, Household debt (indicator), 2015, doi: 10.1787/f03b6469-en.

[19] Reinhart C.M., Reinhart V.R., Rogoff K.S., Public debt overhangs: Advanced economy episodes since 1800, „Journal of Economic Perspectives” 26/3 (2012).

[20] Roxburgh C., Lund S., Daruvala T., Manyika J., Dobbs R., Forn R., Croxson K., Debt and deleveraging: Uneven progress on the path to growth, McKinsey Global Institute, January 2012.

\footnotetext{
${ }^{26}$ M. Zachłod-Jelec, Koncepcja bogactwa gospodarstw domowych. Szacunki dla Polski, „Gospodarka Narodowa" 2008/9, s. 19.
} 
[21] Roxburgh C., Lund S., Wimmer T., Amar E., Atkins C., Kwek J., Dobbs R., Manyika J., Debt and deleveraging: The global credit bubble and its economic consequences, McKinsey Global Institute, January 2010.

[22] Rytelewska G., Huszczonek E., Zmiany w popycie na kredyt gospodarstw domowych, „Materiały i Studia, NBP" 2004/172.

[23] Simpson W., Buckland J., Examining Evidence of Financial and Credit Exclusion in Canada from 1999 to 2005, ,Journal of Socio-economics” 38/6 (2009), s. 966-976.

[24] Zachłod-Jelec M., Koncepcja bogactwa gospodarstw domowych. Szacunki dla Polski, „Gospodarka Narodowa" 2008/9, s. 19-50.

[25] ZBP, Raport Amron-SARFiN, Ogólnopolski raport o kredytach mieszkaniowych i cenach transakcyjnych nieruchomości, III kwartał 2009.

\section{HOUSEHOLD DEBTS AS A DERIVATIVE OF THEIR INCOME}

The objective of this work was an attempt to clarify the links that exist between the level of household debts and the level of income at their disposal. The aim of the paper was to find an answer to the question whether the increase in household debt is due to the insufficient, in the opinion of these entities, income level, or on the contrary - household debt is growing, because in light of their financial situation, they can afford to increase debt. The hypothesis in the article was that: "a higher level of disposable income of households favors the formation of their greater debt." In order to verify this hypothesis research was conducted based on data published by the OECD and the BFG, KNF, NBP and the PBA. The analysis of debt and disposable income of households in selected countries in the world and in Poland was conducted. The research lead to the conclusion that in the more economically developed countries level of household debt in relation to their disposable income is higher than in countries located on the lower level of development. The level of development of a country is linked to the structure of the debt held by households - in countries with a higher level of development there is a predominance of mortgage debt on consumer debt, while in the less developed countries this relationship is reversed. In Poland, the level of household debt as a percentage of disposable income is among the lowest in Europe. The growth rate of the mortgage debt is higher than the general rate of consumption debt growth. Since 2008 , the level of housing debt is higher than the level of consumer debt.

Keywords: household debt, disposable income, housing demand, consumer demand.

DOI: $10.7862 /$ rz.2015.mmr.34

Tekst złożono w redakcji: październik 2015

Przyjęto do druku: październik 2015 